Edi Purnomo. dkk. Pengaruh Pemaparan Karbofuran pada Induk Mencit (Mus musculus)

\title{
PENGARUH PEMAPARAN KARBOFURAN PADA INDUK MENCIT (Mus musculus) TERHADAP GAMBARAN HISTOPATOLOGI GINJAL ANAK MENCIT MASA LAKTASI
}

\section{THE EFFECT OF CARBOFURAN EXPOSURE ON MICE (Mus musculus) AGAINST KIDNEY HISTOPATHOLOGY APPEARANCE OF MICE PUPS DURING LACTATION PERIOD}

\author{
Edi Purnomo 1), Epy Muhammad Luqman 2), Hermin Ratnani 2), Hani Plumeriastuti 2), \\ Maslichah Mafruchati 2), Yeni Dhamayanti 2) \\ 1) Mahasiswa, 2) Dosen \\ Fakultas Kedokteran Hewan Universitas Airlangga \\ Kampus C UNAIR, Jl. Mulyorejo-Surabaya 60115 \\ Telp. 031-5992785, Fax. 031-5993015 \\ Email: jbmvunair@gmail.com
}

\begin{abstract}
Carbofuran is a broad spectrum carbamat insecticide which is used in various farm practices. An exposure of carbofuran has been reported able to induce Reactive Oxygen Species (ROS) or free radical in kidney. Free radical caused cells damage. The present study was designed to investigate the effect of carbofuran in kidneys histopathologic of mice pup whose dam were exposed by carbofuran during the lactation period. High levels of ROS can bind to various biomolecules such as proteins, lipids and nucleic acids so that carbofuran has a negative effect on tissue functions and structures. Free radical caused changes in the pathological conditions of the tissue including the kidneys. The dams were devided into four groups of five animals each. P0 animal group was received aquadest $0,1 \mathrm{ml}$ per body weight (BW), P1 animal group was treated carbofuran at the dose of $1 / 16 \mathrm{LD}_{50}(0,3125 \mathrm{mg}$ per $\mathrm{BW}), \mathrm{P} 2$ animal group was treated carbofuran at the dose of $1 / 8 \mathrm{LD}_{50}(0,625 \mathrm{mg}$ per $\mathrm{BW})$, and $\mathrm{P} 3$ animal group was treated carbofuran at the dose of $1 / 4 \mathrm{LD}_{50}\left(1,25 \mathrm{mg}\right.$ per BW). The carbofuran was exposed via oral postnatal day $1^{\text {st }}$ until $9^{\text {th }}$ postnatal day after delivery. At postnatal day $10^{\text {th }}$, offspring were sacrified. The kidney of mice pup was collected and processed for microscopic examination with hematoxilin-eosin staining. Microscopic observations on the histology of the mice pup kidney showed an increase in the degree of kidney damage as an increase in the dose of carbofuran given to the dams. The results showed tubular changes in the form of tubular degeneration, inflammatory cell infiltration and tubular necrosis in the kidney of mice pups.
\end{abstract}

Key words: carbofuran, lactation, mice pups, kidney

\section{PENDAHULUAN}

Insektisida diperkenalkan di Indonesia sejak tahun 1970. (Indraningsih, 2008). Paparan insektisida bisa masuk ke dalam tubuh melalui makanan, udara, dan air (Mansour and Mossa, 2011). Karbofuran (2,3-dihydro-2,2-dimethyl-7ben-zofuranol methyl carbamate) yang memiliki nama dagang furadan merupakan insektisida berspektrum luas yang biasanya dipakai untuk meningkatkan produktivitas tanaman. (Jaiswal et al., 2013).
Penelitian residu karbofuran pada buah melon di Grobogan Jawa Tengah menunjukkan terdapat residu karbofuran yang melebihi ambang batas yang ditetapkan yaitu $>0,09$ ppm (Hartini dan Asfawi, 2013) . Residu karbofuran pada sampel daging sapi di Blora tahun 2005 mencapai 169,17 ppb $(0,17 \mathrm{mg} / \mathrm{kg})$ melebihi nilai BMR (Batas Maksimum Residu) daging sapi sebesar $50 \mathrm{ppb}(0,05 \mathrm{mg} / \mathrm{kg})$ (Indraningsih, 2008). Sebanyak 187 ekor burung nasar putih Afrika mati disebabkan oleh 
karbofuran di sekitar Sungai Athi, Kenya (Otieno et al., 2010). Penelitian menunjukkan bahwa residu insektisida terdapat pada sirkulasi darah induk, plasenta, darah jantung, dan air susu induk (Dewan et al., 2013).

Kerusakan sel oleh paparan karbofuran dikaitkan dengan pembentukan ROS (reactive oxygen species) atau radikal bebas dalam tubuh (Jaiswal et al., 2013). Radikal bebas atau reactive oxygen species (ROS) adalah senyawa kimia tersusun atas elektron yang tidak berpasangan atau kehilangan elektron, sehingga apabila radikal bebas bertemu dengan molekul non radikal maka radikal bebas mengambil elektron dari molekul sel di sekitarnya. Ikatan antara radikal bebas dan sel pada makhluk hidup bersifat toksik (Werdhasari, 2014). Tanda-tanda klinis keracunan insektisida golongan karbamat antara lain lemah, sakit kepala, berkeringat, hipersalivasi, muntah, dan diare (Indraningsih, 2008).

Ginjal menjadi target rentan stres oksidatif. Hal ini disebabkan ginjal memiliki PUFA (poly unsaturated fatty acids) yang banyak (Ozbek, 2012). Radikal bebas bereaksi dengan PUFA sehingga terjadi peroksidasi lipid. Peroksidasi lipid adalah proses suatu oksidan berperan sebagai radikal bebas bereaksi dengan lemak yang mengandung ikatan rangkap karbon. Peroksidasi lipid merangsang terjadinya kerusakan jaringan (Ayala et al., 2014).

Seorang perempuan mungkin saja bisa terpapar karbofuran dari lingkungan sekitar yang bisa berdampak pada bayi yang disusui termasuk berasal dari makanan. Hal tersebut bisa saja menyebabkan kerusakan pada ginjal bayi yang sedang menyusui.

Penelitian ini bertujuan untuk mengetahui histopatologi ginjal anak mencit yang mendapat air susu dari induk yang terpapar karbofuran selama periode laktasi.

\section{MATERI DAN METODE PENELITIAN}

\section{Alat dan Bahan Penelitian}

Alat yang digunakan dalam penelitian ini adalah kandang mencit, tempat pakan dan minum mencit, mikroskop Olympus ${ }^{\circledR}$ CX-41, sonde lambung, peralatan bedah (pinset, skapel, gunting bedah), glove, masker, object glass, cover glass, kawat jala, toples anastesi, cawan petri, alkohol spray, timbangan analitik,kertas buram, dan pot salep. Bahan yang digunakan dalam penelitian ini adalah mencit, karbofuran 98\% produksi Aldrich Chemistry, aquades, pakan mencit produksi PT Japfa Comfeed, ether, alkohol 70\%, formalin $10 \%$, dan air minum.

\section{Persiapan Hewan Coba}

Mencit betina strain Balb/C yang sudah bunting dibagi menjadi empat kelompok yaitu P0, P1, P2, dan P3. Tiap kelompok terdiri dari lima kali ulangan.

\section{Penentuan Dosis}

Mencit jantan dipakai untuk menentukan nilai $\mathrm{LD}_{50}$ sebelum diberikan kepada mencit bunting. Nilai $\mathrm{LD}_{50}$ ditentukan dari 50\% jumlah mencit jantan yang mati akibat paparan karbofuran, kemudian penentuan dosis supaya mencit betina tidak mati selama sembilan hari post partus. Selanjutnya, dilakukan degradasi dosis melaui fraksi kelipatan misal 1/4, 1/8 $\mathrm{LD}_{50}$ dan seterusnya sampai diperoleh angka harapan hidup 10 hari setelah pemaparan.

\section{Induksi Menggunakan Karbofuran}

Induk yang dipapar karbofuran fraksi $1 / 4,1 / 8$, dan $1 / 16$ dari $\mathrm{LD}_{50}$ pada masa laktasi hari ke 1-9 diberikan secara peroral menggunakan sonde steril sekali pakai. Induk mencit kontrol diberikan larutan aquades. Setiap kandang diisi satu induk mencit beserta anak-anaknya 
dan diletakkan dengan rak kelompok yang sama sebagai ulangan tiap perlakuan. Pada hari ke-10 setelah kelahiran, anak mencit dikorbankan untuk pengambilan sediaan ginjal dan pembuatan preparat histologi.

\section{Pengamatan Preparat Histologi}

Pengamatan preparat histologi ginjal dilakukan dengan mikroskop perbesaran 100x dan 400x dengan pengamatan pada lima lapangan pandang yang berbeda dari tiap sediaan. Skor kerusakan ginjal ditampilkan pada tabel berikut:

\begin{tabular}{|c|c|}
\hline Skor & Degenerasi sel tubulus ginjal \\
\hline 0 & $\begin{array}{l}\text { Tidak terdapat degenerasi yang } \\
\text { terjadi }\end{array}$ \\
\hline 1 & $\begin{array}{l}\text { Terdapat degenerasi sel tubulus } \\
<25 \% \text { pada lapangan pandang }\end{array}$ \\
\hline 2 & $\begin{array}{l}\text { Terdapat degenerasi sel tubulus } \\
26-50 \% \text { pada lapangan pandang }\end{array}$ \\
\hline 3 & $\begin{array}{l}\text { Terdapat degenerasi sel tubulus } \\
51-75 \% \text { pada lapangan pandang }\end{array}$ \\
\hline 4 & $\begin{array}{l}\text { Terdapat degenerasi sel tubulus } \\
>76 \% \text { pada lapangan pandang }\end{array}$ \\
\hline Skor & Nekrosis sel tubulus ginjal \\
\hline 0 & $\begin{array}{l}\text { Tidak terdapat nekrosis yang } \\
\text { terjadi }\end{array}$ \\
\hline 2 & $\begin{array}{l}\text { Terdapat nekrosis sel tubulus } \\
<25 \% \text { pada lapangan pandang }\end{array}$ \\
\hline 4 & $\begin{array}{l}\text { Terdapat nekrosis sel tubulus } \\
26-50 \% \text { pada lapangan pandang }\end{array}$ \\
\hline 6 & $\begin{array}{l}\text { Terdapat nekrosis sel tubulus } \\
51-75 \% \text { pada lapangan pandang }\end{array}$ \\
\hline 8 & $\begin{array}{l}\text { Terdapat nekrosis sel tubulus } \\
>76 \% \text { pada lapangan pandang }\end{array}$ \\
\hline Skor & Infiltrasi sel radang \\
\hline 0 & $\begin{array}{l}\text { Tidak ditemukan infiltrasi sel } \\
\text { radang }\end{array}$ \\
\hline 1 & $\begin{array}{l}\text { Ditemukan infiltrasi sel radang } \\
<25 \% \text { pada lumen interstitial }\end{array}$ \\
\hline 2 & $\begin{array}{l}\text { Ditemukan infiltrasi sel radang } \\
26-50 \% \text { pada lumen interstitial }\end{array}$ \\
\hline 3 & $\begin{array}{l}\text { Ditemukan infiltrasi sel radang } \\
51-75 \% \text { pada lumen interstitial }\end{array}$ \\
\hline 4 & $\begin{array}{l}\text { Ditemukan infiltrasi sel radang } \\
>76 \% \text { pada lumen interstitial }\end{array}$ \\
\hline
\end{tabular}

\section{Analisis Data}

Uji statistik untuk menghitung skor infiltrasi sel radang, degenerasi dan nekrosis menggunakan Rancangan Acak lengkap (RAL). Perhitungan data menggunakan SPSS (Statistical Programs for Social Scientific) versi 21 yaitu uji Kruskal Wallis dilanjutkan dengan uji Mann Whitney.

\section{HASIL DAN PEMBAHASAN}

Paparan karbofuran dalam tubuh menyebabkan adanya reactive oxygen species (ROS) dalam tubuh (Jaiswal et al., 2013). Konsentrasi ROS yang tinggi berbahaya bagi makhluk hidup (Sharma et al., 2012). Insektisida menyebabkan terjadinya radikal bebas yang memicu kerusakan mitokondria sehingga timbul stres oksidatif (Kaur et al., 2012).

Radikal bebas menyebabkan peroksidasi lipid pada jaringan. Karbofuran bersifat lipofilik sehingga bisa berikatan dengan membran sel. Reaksi ROS dan lipid membentuk hidroksil radikal. Hidroksil radikal memiliki struktur yang kecil, mobilitas tinggi, larut dalam air, dan senyawa radikal paling aktif. Radikal hidroksil diproduksi dari molekul oksigen dalam metabolisme sel dibawah kondisi stres. Radikal hidroksil menyerang berbagai jenis sel karena mereka menyerang berbagai biomolekul secara tidak spesifik. Hal ini menyebabkan terjadinya kerusakan sel (Ayala et al., 2014).

\section{Degenerasi Tubulus Ginjal}

Pengamatan degenerasi secara mikroskopis dilakukan dengan menggunakan preparat histopatologi ginjal anak mencit (Mus musculus) pewarnaan HE. Hasil pengamatan degenerasi ginjal anak mencit dapat diamati pada tabel 1. 
Tabel 1. Degenerasi tubulus ginjal anak mencit akibat paparan karbofuran pada induk masa laktasi

\begin{tabular}{|c|c|}
\hline Perlakuan & $\begin{array}{c}\text { Skor Degenerasi } \\
\text { Tubulus } \\
\text { (Median } \pm \text { SD) }\end{array}$ \\
\hline P0 (Kontrol) & $0,40 \pm 0,11^{\text {a }}$ \\
\hline P1 (1/16 LD 50$)$ & $1,53 \pm 0,36^{\mathrm{b}}$ \\
\hline P2 (1/8 LD 50$)$ & $2,07 \pm 0,16^{\mathrm{c}}$ \\
\hline P3 (1/4 LD 50$)$ & $3,00 \pm 0,97^{\mathrm{d}}$ \\
\hline
\end{tabular}

Keterangan: superskrip yang berbeda dalam kolom yang sama menunjukkan perbedaan yang nyata $(\mathrm{p}<0,05)$.

Berdasarkan tabel 1, hasil analisis statistik menunjukkan bahwa antara kelompok P0 dengan semua kelompok perlakuan terdapat perbedaan yang signifikan $(p<0,05)$. Kelompok P0 menunjukkan terjadi degenerasi dengan derajat kerusakan kurang dari 25\%. Hal ini diduga karena radikal bebas akibat faktor luar seperti stres panas lingkungan yang bisa memicu perubahan histologi jaringan. Antioksidan endogen dalam tubuh anak mencit diduga masih mampu untuk menyeimbangkan kadar radikal bebas dalam tubuh sehingga kerusakan yang terjadi minimal (Werdhasari, 2014). Kelompok P1, P2, dan P3 terjadi degenerasi tubulus yang semakin meningkat sebanding dengan dosis karbofuran yang diberikan pada induk mencit. Daya ketoksikan suatu senyawa dalam tubuh dipengaruhi oleh dosis pemberian, lama pemaparan, cara pemberian, dan variasi antar individu dan spesies (Ndaong dkk., 2014). Peroksidasi lipid akibat ROS menyebabkan kerusakan jaringan (Jaiswal et al., 2013).

Manifestasi pertama kerusakan jaringan adalah pembengkakan sel yang muncul akibat sel tidak mampu mempertahankan homeostasis ion dan cairan (Arimbi dkk., 2015).

Pengamatan mikroskopis pada sediaan histologi organ ginjal anak mencit ditemukan degenerasi hidropis pada kelompok perlakuan. Degenerasi tubulus ditandai dengan pembengkakan sitoplasma sel sehingga lumen tampak menyempit. Penelitian sejenis yang dilakukan oleh Mansour et al. (2008) menunjukkan hal yang sama lumen tubulus ginjal mengalami penyempitan akibat adanya pembengkakan tubulus.

Hasil penelitian menunjukkan derajat degenerasi meningkat seiring jumlah dosis yang diberikan. Hal ini sesuai dengan penelitian yang dilakukan Luqman et al. (2018) yang menyatakan bahwa paparan karbofuran dipengaruhi oleh durasi paparan dan jumlah dosis yang diberikan untuk menghasilkan efek pada tubuh.

Gambaran degenerasi tubulus ditunjukkan gambar 1.

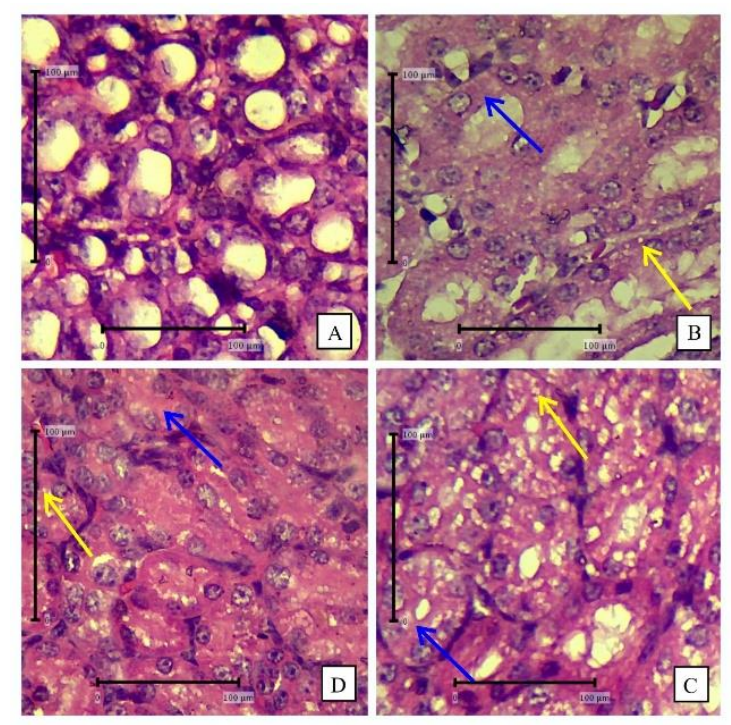

Gambar 1. Degenerasi hidrofik pada tubulus ginjal ditandai dengan panah biru. Degenerasi melemak ditandai dengan panah kuning. $\mathrm{A}=\mathrm{P} 0, \mathrm{~B}=\mathrm{P} 1$, $\mathrm{C}=\mathrm{P} 2$, dan $\mathrm{D}=\mathrm{P} 3$. Perbesaran 400x. 
Perubahan pada tubulus ginjal ditemukan degenerasi melemak. Degenerasi melemak ditandai dengan vakuola-vakuola lemak kecil di sitoplasma tubulus sehingga jaringan tampak jernih. Peroksidasi lipid oleh ROS menyebabkan lisis pada membran sel dan retikulum endoplasmik sehingga menurunkan sintesis enzim apoprotein untuk mengikat trigliserida. Dampak gangguan sintesis apoprotein adalah lemak tertimbun dalam sitoplasma sehingga terjadi degenerasi melemak (Arimbi dkk., 2015).

Degenerasi melemak ditandai dengan akumulasi lemak dalam sitoplasma sel. Bentuk degenerasi ini biasanya terdapat pada tubulus ginjal, hepar, myocard dan sebagainya. Pada pewarnaan HE, lemak yang hilang akibat proses dehidrasi dengan alkohol membentuk vakuola. Inti sel terdesak ke pinggir akibat penimbunan lemak dalam sitoplasma (Adinata dkk., 2016). Degenerasi melemak biasanya disebabkan oleh toksin, malnutrisi protein, diabetes melitus, obesitas, dan anoksia.

\section{Infiltrasi Sel Radang}

Infiltrasi sel radang diamati menggunakan preparat histopatologi ginjal anak mencit (Mus musculus) dengan pewarnaan HE. Pengamatan infiltrasi sel radang dilakukan di interstitial tubulus ginjal. Hasil pengamatan infiltrasi sel radang dapat dilihat pada tabel 2 .

Tabel 2. Infiltrasi sel radang pada lumen interstitial ginjal anak mencit akibat paparan karbofuran pada induk masa laktasi

\begin{tabular}{|c|c|}
\hline Perlakuan & $\begin{array}{c}\text { Skor Infiltrasi Sel } \\
\text { Radang } \\
\text { (Median } \pm \text { SD) }\end{array}$ \\
\hline P0 (Kontrol) & $0,13 \pm 0,08^{\mathrm{a}}$ \\
\hline P1 (1/16 LD 50$)$ & $1,20 \pm 0,25^{\mathrm{b}}$ \\
\hline P2 $\left(1 / 8 \mathrm{LD}_{50}\right)$ & $2,13 \pm 0,38^{\mathrm{c}}$ \\
\hline P3 $\left(1 / 4 \mathrm{LD}_{50}\right)$ & $2,33 \pm 0,34^{\mathrm{c}}$ \\
\hline
\end{tabular}

Keterangan: superskrip yang berbeda dalam kolom menunjukkan perbedaan yang nyata $(\mathrm{p}<0,05)$.

Berdasarkan tabel 4.2. hasil analisis statistik menunjukkan bahwa antara kelompok P0 dengan semua kelompok perlakuan terdapat perbedaan yang signifikan $(p=0,001)$. Kelompok P1, P2, dan P3 menunjukkan terjadi peningkatan infiltrasi sel radang pada lumen interstitial ginjal anak mencit sebanding dengan dosis karbofuran yang dipaparkan pada induk mencit masa laktasi. Infiltrasi sel radang tertinggi terdapat pada kelompok P3 meskipun tidak terdapat perbedaan yang nyata $(p=0,34)$ dengan kelompok P2. Infiltrasi sel radang terendah terdapat pada kelompok P0. Infiltrasi sel radang ginjal anak mencit ditunjukkan gambar 2. Metabolit karbofuran dalam air susu induk menyebabkan peroksidasi lipid dalam ginjal sehingga terjadi sekresi prostaglandin dan leukotrien. Hal itu merangsang sintesis mediator inflamasi interleukin (IL)-1, IL-8, dan TNF a yang meningkatkan proses inflamasi. Selanjutnya, respon tersebut menyebabkan perubahan respon imun dan aktivasi sel mast (Danusantoso, 2003).

Pada pengamatan histopatologi ginjal anak mencit, kelompok perlakuan 
terjadi infiltrasi sel radang di lumen interstitial ginjal. Hal ini mengindikasikan bahwa terdapat radang pada jaringan ginjal akibat paparan karbofuran.

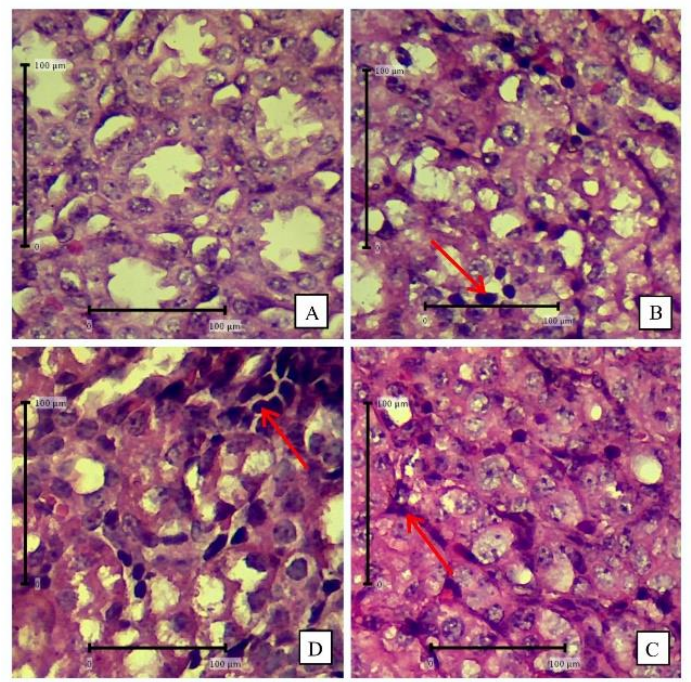

Gambar 2. Infiltrasi sel radang pada interstial ginjal anak mencit ditunjukkan panah merah. $\mathrm{A}=\mathrm{P} 0, \mathrm{~B}=\mathrm{P} 1, \mathrm{C}=\mathrm{P} 2$, dan $\mathrm{D}=\mathrm{P}$. Perbesaran $400 \mathrm{x}$

Kelompok P2 dan P3 menunjukkan peningkatan infiltrasi sel radang meskipun tidak terdapat perbedaan yang nyata $(p>0,05)$. Hasil ini diduga karena perbedaan individu masing-masing anak mencit berkaitan dengan daya tahan tubuh dan imunitas yang berbeda.

Sel radang yang ditemukan pada jaringan ginjal mengindikasikan bahwa terdapat metabolit karbofuran dalam air susu. Infiltrasi sel radang merupakan respon tubuh terhadap kerusakan dalam jaringan yang bisa diakibatkan oleh agen patogen, sel mati atau rusak, iritasi, benda asing, cedera fisik, luka bakar, radiasi, maupun senyawa beracun (Arimbi dkk., 2015). Zat toksik yang hilang akan menyebabkan reaksi radang berakhir. Inhibitor sitokin seperti antagonis reseptor sitokin dan asetil hidrolase akan mengakhiri proses inflamasi (Farida, 2003).

\section{Nekrosis Tubulus Ginjal}

Pengamatan nekrosis tubulus ginjal anak mencit dilakukan dengan menggunakan preparat histopatologi ginjal anak mencit (Mus musculus) pewarnaan HE. Nekrosis tubulus ditandai dengan adanya piknotis, karyoreksis, dan karyolisis. Derajat nekrosis tertinggi terdapat pada kelompok P3, sedangkan derajat nekrosis terendah terdapat pada kelompok P0. Hasil pengamatan nekrosis tubulus dapat dilihat pada tabel 4.3.

Tabel 3. Nekrosis tubulus ginjal anak mencit akibat paparan karbofuran pada induk masa laktasi

\begin{tabular}{|c|c|}
\hline Perlakuan & $\begin{array}{c}\text { Skor Nekrosis } \\
\text { Tubulus } \\
\text { (Median } \pm \text { SD) }\end{array}$ \\
\hline P0 (Kontrol) & $0,00 \pm 0,00^{\mathrm{a}}$ \\
\hline P1 (1/16 LD 50$)$ & $0,67 \pm 0,40^{\mathrm{b}}$ \\
\hline P2 (1/8 LD 50$)$ & $1,07 \pm 0,20^{\mathrm{c}}$ \\
\hline P3 $\left(1 / 4 \mathrm{LD}_{50}\right)$ & $1,47 \pm 0,08^{\mathrm{d}}$ \\
\hline
\end{tabular}

Keterangan: superskrip yang berbeda menunjukkan perbedaan yang nyata $(\mathrm{p}<0,05)$.

Berdasarkan tabel 3, hasil analisis statistik antara kelompok P0 dengan semua kelompok perlakuan terdapat perbedaan yang signifikan $(p=0,001)$. Kelompok P1, P2, dan P3 mengalami peningkatan nekrosis sebanding dengan dosis karbofuran yang diberikan pada induk masa laktasi. Senyawa metabolit karbofuran dalam air susu induk mencit dapat mengakibatkan terjadinya nekrosis pada anak mencit. Radikal bebas memicu terjadinya deplesi ATP dan merangsang pengeluaran enzim proteolitik sehingga terjadi nekrosis (Guanovora dkk., 2016). 
Pada pengamatan histopatologi ginjal anak mencit terjadi perubahan berupa piknotis, karyoreksis, dan karyolisis pada kelompok perlakuan, sedangkan kelompok kontrol terlihat normal. Piknotis ditandai dengan inti sel memadat warna hitam, karyoreksis ditandai dengan inti memudar, dan karyolisis ditandai inti menghilang.

Nekrosis pada ginjal anak mencit ditunjukkan gambar 3.

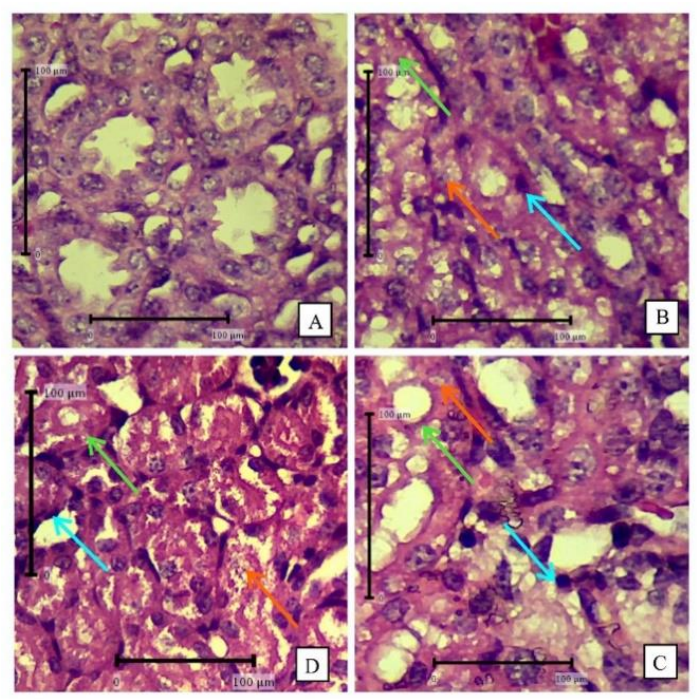

Gambar 3. Nekrosis pada tubulus ginjal anak mencit. Piknotis ditunjukkan warna biru muda, karyoreksis ditunjukkan warna oranye, dan karyolisis ditunjukkan oleh panah hijau. $\mathrm{A}=\mathrm{P} 0, \mathrm{~B}=\mathrm{P} 1, \mathrm{C}=\mathrm{P} 2$, dan $D=P 3$. Perbesaran 400x.

Hasil rata-rata skoring ginjal anak mencit menunjukkan nekrosis yang terjadi adalah kurang dari $25 \%$ dari lapangan pandang. Hal ini diduga terkait kadar senyawa metabolit karbofuran dalam air susu induk. Konsentrasi insektisida dalam tubuh berturut-turut dari tinggi ke rendah yaitu dalam darah induk, plasenta, darah dalam umbilical cord, dan air susu (Dewan et al., 2013). Faktor lain yang mempengaruhi kecepatan nekrosis ginjal adalah upaya pertahanan sel melalui pertahanan antioksidan dalam ginjal sehingga menghasilkan respon adaptif (Ayala et al., 2014).
Kadar antioksidan tidak cukup mengimbangi kerusakan radikal bebas sel akan mengalami nekrosis (Ayala et al., 2014). Selain itu, lama paparan karbofuran mempengaruhi terjadinya nekrosis. Struktur seluler berupa DNA dan mitokondria memerlukan waktu paparan yang lebih lama untuk terjadi kerusakan akibat stres oksidatif (Yunus dan Ratna, 2012). Nekrosis adalah kematian sel ketika individu masih hidup. Nekrosis dapat disebabkan oleh zat toksik, infeksi mikroorganisme, gangguan metabolisme, dan lain-lain (Suhita dkk., 2013).

\section{KESIMPULAN}

Karbofuran dapat menyebabkan perubahan histopatologi ginjal anak mencit berupa degenerasi tubulus, infiltrasi sel radang, dan nekrosis tubulus yang diperoleh dari air susu induk. Derajat kerusakan ginjal anak mencit meningkat seiring pemberian dosis karbofuran pada induk mencit masa laktasi.

\section{DAFTAR PUSTAKA}

Adinata, M.O., I.W. Sudira, dan I.K. Berata. 2012. Efek Ekstrak Daun Ashitaba (Angelica keiskei) Terhadap Gambaran Histopatologi Ginjal Mencit (Mus musculus) Jantan. Jurnal Buletin Veteriner Udayana 4(2): 55-62.

Arimbi, A. Azmijah, R. Darsono, H. Plumeriastuti, T. V. Widiyatno dan D. Legowo. 2015. Buku Ajar Patologi Umum Veteriner Edisi Ke-2. Surabaya. Airlangga University Press. 73.

Ayala, A., M.F. Munoz, and S. Arguelles. 2014. Lipid Peroxidation: Production, Metabolism, and Signalling Mechanism of Malondialdehyde and 4-Hydroxy-2-Nonenal. Hindawi Journal: 1-31. 
Danusantoso, H., 2003. Peran Radikal Bebas Terhadap Beberapa Penyakit Paru. Jurnal Kedokteran Trisakti 22(1): 31-36.

Dewan, P., V. Jain, P. Gupta, and P.D. Banerjee. 2013. Organochlorine Pestiside Residues in Maternal Blood, Cord Blood, Placenta, and Breastmilk and Their Relation on Birth Size. Elsevier Journal: 17041710.

Farida, R. 2003. Reaksi Radang. Jurnal Kedokteran Gigi Universitas Indonesia: 468-472.

Guanovora, N., T.S. Mallo, dan D. Tomuka. 2016. Kecepatan Rigor Mortis Pada Intoksikasi Insektisida Golongan Organofosfat Pada Kelinci. Jurnal E-Clinic 4(1): 21-30.

Hartini, E. dan S. Asfawi. 2013. Kontaminasi Residu Pestisida Dalam Buah Melon Di Kabupaten Grobogan. Universitas Dian Nuswantoro. Semarang. Hal. 20.

Indraningsih. 2008. Pengaruh Penggunaan Insektisida Karbamat terhadap Kesehatan Ternak dan Produknya. Jurnal Wartazoa 18(2): 101-114.

Jaiswal, S.K., N.J. Siddiqi, and B. Sharma. 2013. Carbofuran Induced Oxidative Stress in Rat Heart: Ameliorative Effect of Vitamin C. Hindawi Publishing Corporation Journal: 1-10.

Luqman, E.M., Widjiati, and L.R. Yustinasari. 2018. Brain Cells Death on Infant Mice (Mus musculus) Caused by Carbofuran Exposure During Lactation Period. Kafkas University
Veteriner Faculty Dergisi Journal 24(6): 845-852.

Mansour, T.M. Haikal, A.H. Mossa, and A.A. Refaie. 2008. Toxic Effects of Five Insecticides On Their Mixture On Male Albino Rats. Egypt Society Toxycology Journal 39: 85-94.

Mansour, S.A. and A.T.H. Mossa. 2011. Adverse Effects of Exposure to Low Doses of Chlorpyrifos in Lactating Rats. J. Toxicology and

Ndaong, N.A., A.D. Wijayanti, dan S. Widyarini. 2014. Efek Pemaparan Deltamethrin pada Broiler Terhadap Aktivitas Enzim Alanin Aminotransferase, Aspartat Aminotransferase dan Gambaran Histopatologi Hepar. Jurnal Kajian Veteriner 2(1): 79-87.

Otieno, P.O., J.O. Lalah, M. Virani, I.O. Jondiko, and K.W. Schram. 2010. Carbofuran and its Toxic Metabolites Provide Forensic Evidence for Furadan Exposure in Vultures (Gyps africanus) In Kenya. Springer Journal 84: 536544.

Ozbek, E. 2012. Induction of Oxidative Stress in Kidney. Hindawi Journal: 1-9.

Rekha, S. Raina, and S. Hamid. 2013. Histopathological Effects of Pesticide-Cholopyrifos on Kidney in Albino Rats. International Journal Research Medicine Science. 1(4): 465-475. 
Edi Purnomo. dkk. Pengaruh Pemaparan Karbofuran pada Induk Mencit (Mus musculus)

Sharma, R.K., S.K. Jaiswal, N.J. Shiddiqi, and B. Sharma. 2012. The Effect of Carbofuran On Some Biochemichals Indices of Human Erythrocytes in Vitro. Cellular and Molecular Biology Journal 58 (1): 103-109.

Suhita, N.L. Putu Ratna, I.W. Sudira, dan I.B. Oka Winarya. 2013. Histopatologi Ginjal Tikus Putih Akibat Pemberian Ekstrak Pegagan (Centella asiatica) Peroral. Jurnal Buletin Veteriner Udayana 5(1): 62-68.
Sutisna. 2013. Penyakit Degeneratif. Seminar Nasional Universitas Muhammadiyah Surakarta: 1-7.

Werdhasari, A. 2014. Peran Antioksidan Bagi Kesehtan. Jurnal Biotek Medisiana Indonesia. 3(2): 59-68.

Yunus, J., dan D.C. Ratna. 2012. Efek Neuroprotekt if Vitamin $\mathrm{D}_{3}$ Terhadap Jumlah Sel Purkinje Serebellum Yang Diinduksi Etanol. Jurnal Mutiara Medika 12(2): 63-71. 